\title{
Problem Solving Styles, Approaches to Learning and Academic Performance of Spanish Accounting Students: An Exploratory Study of Profiles and Relationships.
}

\author{
José L. Arquero (arquero@us.es) \\ http://orcid.org/0000-0002-7086-8812 \\ José A. Donoso (jadonoso@us.es) \\ https://orcid.org/0000-0001-7454-1078 \\ http://dx.doi.org/10.12795/EDUCADE.2019.i10.02
}

\begin{abstract}
:
Background. Entwistle Students' Approaches to Learning framework and Kolb's Experiential Learning Model has been widely used in higher education. Different inventories have been developed in order to adapt to different contexts and / or to supersede reported weakness.

Aims. This paper aims to explore the profiles and approaches showed by a sample of Spanish accounting students as well as the relationship of those profiles with the academic performance.

Instrument and Sample. The instrument consists of both the short version of the Study Process Questionnaire (SPQ; Fox et al, 2001) and the Problem Solving Style Questionnaire (PSSQ, Romero et al, 1992). The sample is composed by the students enrolled in advanced financial accounting and financial statement analysis at the University of Sevilla.
\end{abstract}

Results. Contrariwise to reported results in our area, but in different countries, Spanish accounting students mainly present diverger learning style, followed by assimilator style. A strong, negative correlation is found between the score on surface approach and the academic performance in the accounting courses. Although there is no difference in grades by style preference, there is a positive correlation in the score CE-AC, which suggest that students scoring high to abstract conceptualization pole tend to obtain higher grades.

KEYWORDS: Learning styles, PSSQ, Approaches to learning, SPQ, Kolb.

Nota de investigación. Recibido: 01-12-19 - Aceptado: 20-12-19

Licencia Creative Commons BY NC ND · $2019 \cdot$ Universidad de Sevilla - AECA

\section{INTRODUCTION}

Students' approach to learning (SAL) is a conceptual framework derived from the work of Marton and Säljö (1976). As Biggs et al (2001) indicate, an approach to learning describes the nature of the relationship between student, content and task. The choice an individual could make is usually categorized into two basic strategies (Byrne et al, 2004b): deep level processing and surface level processing. Many instruments are based upon SAL framework. From the initial 64 items Approaches to Studying Inventory, ASI, (Entwistle et al, 1979) to the 44 items version (Entwistle and Tait, 1995), and the further developments of Biggs (1985), all of them maintain those basic approaches. Later developments reduced the number of items in order to obtain instruments easy to use along with other instruments. The two factors Study Process Questionnaire (SPQ)

educade, no 10, 2019, p. 3 
(Biggs et al 2001), the shortened SPQ (Fox et al, 2001) and the N-SPQ-3f (FernándezPolvillo \& Arquero, 2015) could be included in this last group.

When adopting a deep approach, students try to extract meanings from the contents and tasks, relating the content with other knowledge, real situations, etc. In the other hand, when adopting a surface approach, the aim of the students is merely instrumental (to pass the subject) and, therefore, students try just to reproduce the material (Lucas, 2001).

Our research uses the Problem Solving Style Questionnaire (PSSQ) and the shortened version of SPQ (Fox et al, 2001), exploring profiles and relationships.

The paper is structured as follows: Learning styles (ELM) and approaches to learning framework are presented, as well as the most used inventories. Sample and results section present the main results obtained; ending with the conclusion, extensions and limitations section.

\section{LEARNING STYLES AND APPROACHES TO LEARNING}

\subsection{Learning styles and Kolb's Experiential Learning Model}

Previous research has associated learning styles (in terms of Kolb's Experiential Learning Model -ELM-) to student performance, professional orientation and experience or career choice (Baker et al., 1986; Collins \& Milliron, 1987; Brown \& Burke, 1987) performance in specific scenarios (Bostrom, Olfman \& Sein, 1990) even differences between countries (McKee et al. 1992).

Kolb's learning style inventory $(1976,1984,1985)$ was commonly used in higher and further education. The ELM could be classified as focused in information processing (Curry, 1987) and learning centred (Rayner \& Riding, 1997). This model proposes (following Cassidy, 2004) a four stage learning cycle, where individuals show a preference in a continuous and interactive process. These four stages are concrete experience ( $C E$, experiencing), abstract conceptualization ( $A C$, thinking), active experimentation ( $A E$, doing) and reflective observation ( $R O$, reflecting). Those four stages form two dimensions: prehension defined by the bipolar dimension CE-AC (experiencing-thinking) and transformation $A E-R O$ (doing-reflecting). The position of an individual along those dimensions allows classifying his/her learning styles as converger, diverger, assimilator or accommodator (see figure 1) 


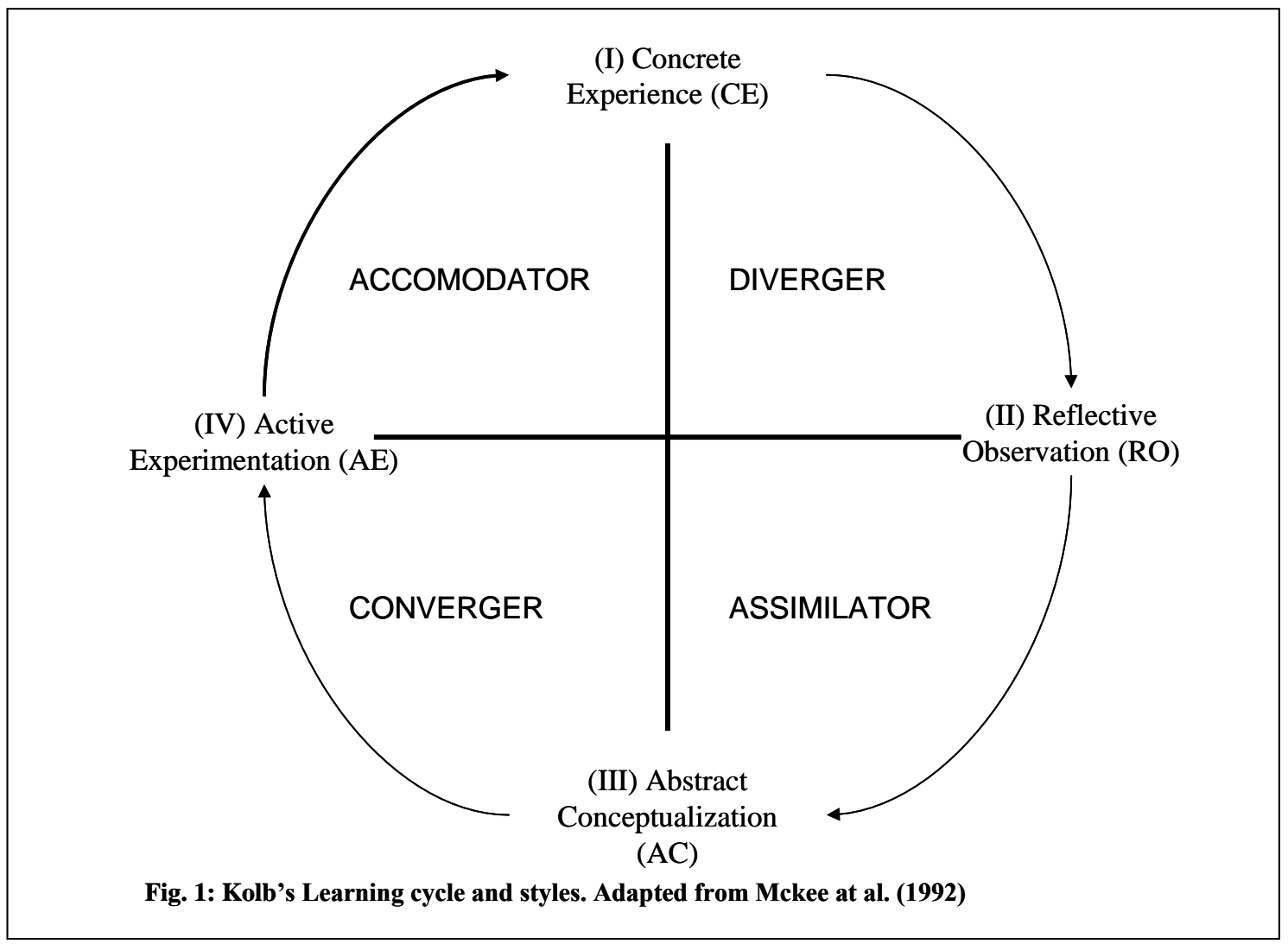

Following Baker et al (1986), the converger's dominant learning abilities are abstract conceptualization (AC) and active experimentation (AE). Convergers prefer the practical application of ideas, perform well in typical intelligence test, are able to apply hypothetico-deductive reasoning, and tend to prefer working with things rather than with people. Divergers are the opposite, learns though concrete experience (CE) and reflective observation (RO). Imaginative, they have broad cultural interests. The assimilator learning preferences are abstract conceptualization (AC) and reflective observation (RO). Strongly theory driven, inductive reasoning is their strong point. On the other side, assimilators like to do things. They solve problems on a trial and error manner.

Alternatives, based on the ELM, were developed to supersede limitations or to adapt to certain contexts. Honey \& Mumford's Learning Styles Questionnaire (LSQ, 1992) was clearly focused and developed for managerial context. However, many research studies raised limitations of LSQ and LSI due to weakness in their psychometric properties (Stout \& Ruble, 1991a-b, 1994; Swailes \& Senior, 1999; Duff \& Duffy, 2002; Duff, 2004a).

Romero et al (1992) developed a new instrument, the Problem Solving Style Questionnaire (PSSQ) also grounded in ELM, eliminating the ipsativity problem raised by Stout and Ruble (1994) and showing adequate validity and reliability properties (Tepper et al, 1993). PSSQ consist of 14 items; seven for each dimension (AC-CE abstract conceptualization - concrete experience and AE-RO active experimentation reflective observation). Each item must be responded in a 6 points scale between two self-descriptive statement anchors. The six points scale was chosen in order to force the election between statements; also, two items per scale are reflected to reduce 
acquiescence. The internal consistency reported in Tepper et al (1993) is 0.76 for AE-RO scale and 0.74 for AC-CE dimensions.

\subsection{Approaches to learning}

Approaches to learning were developed from an early qualitative research (Marton \& Säljö, 1976) which, from a phenomenological perspective tried to understand learning processes by asses students' experience of learning and the ways in which they make sense of the individual approach to the task prescribed in their courses (Duff, 2004).

Hall et al (2004) highlight the different main sources from which recent research has been developed: the Lancaster group (Entwistle \& Wilson, 1970; Entwistle et al, 1974), the Australian group (Biggs, 1978, 1987), the Swedish group (Marton \& Säljö, 1976) and the Richmond group (Pask, 1976). Some of those researchers adopted quantitative methods, resulting on inventories and instruments -Entwistle et al. and Biggs- that became widespread used in higher education.

All that body of research identified to main approaches to learning: surface and deep approach.

A student taking a surface approach acquire the knowledge needed to pass the subject or the task, relies on memorisation and do not try to connect concepts "learned" with previous knowledge, or to look for implications. Hall et al. (2004) indicate that surface approach is externally and assessment focused and tends to result in low engagement with the subject.

Contrariwise, deep approach is defined by a personal interest in learning. The student looks for meaning and tries to connect new knowledge with previous concepts. In many aspects, deep and surface approaches are similar to rote and meaningful learning as defined by constructivists (Ausubel, 1968). Characteristics of both approaches could be summarized as follows:

Table 1: Characteristics associated to approaches.

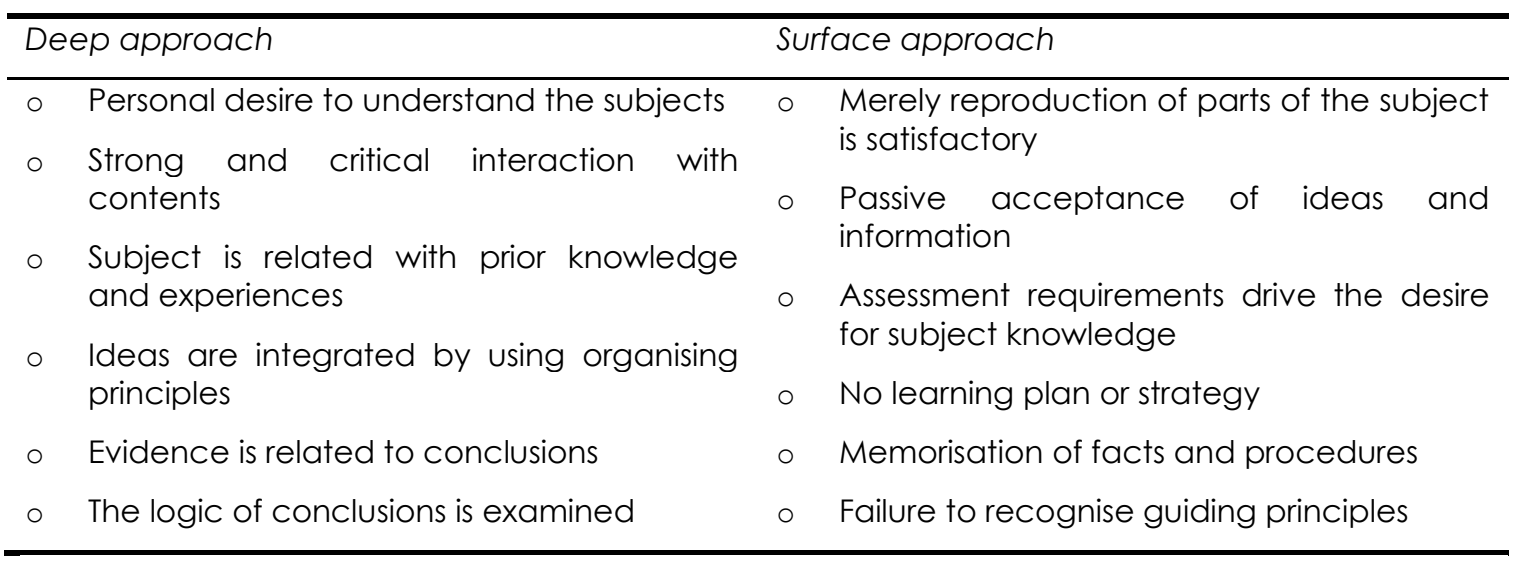

Adapted from Hassall \& Joyce (2001)

As Duff (2004c) notes, a key finding is that students' approach to learning is not only due to personal characteristics, but reflects, at least in part, their response to their 
perception of the learning environment (actual and past). This continuous influence between contextual factors, personal characteristics and approach could be represented in the $3 \mathrm{P}$ model of teaching and learning (figure 2, adapted from Biggs et al. 2001).

\section{- Approaches to Studying Inventory, ASI.}

Following Duff (2004c), ASI (Entwistle et al., 1979) as been one of the most widely used instruments in higher education (see Duff, 2004b for a review). The original inventory was revised in depth in the early 90's. Revised ASI consisted of 60 items, measuring five dimensions: deep, surface, strategic, apathetic and strategic approaches, plus academic attitude. A reduced 38 items version (Entwistle \& Entwistle, 1991) was developed, including five dimensions: deep, surface and strategic approaches, lack of direction and academic self-confidence. The 1995 version (Tait \& Entwistle, 1995) consisted of 44 items and added a sixth dimensions over the former version: metacognitive awareness. Finally a 30 items reduced version of 1995 RASI focuses in the three main dimensions: deep, surface and strategic approach (see Duff, 1999).
Presage
Process
Product

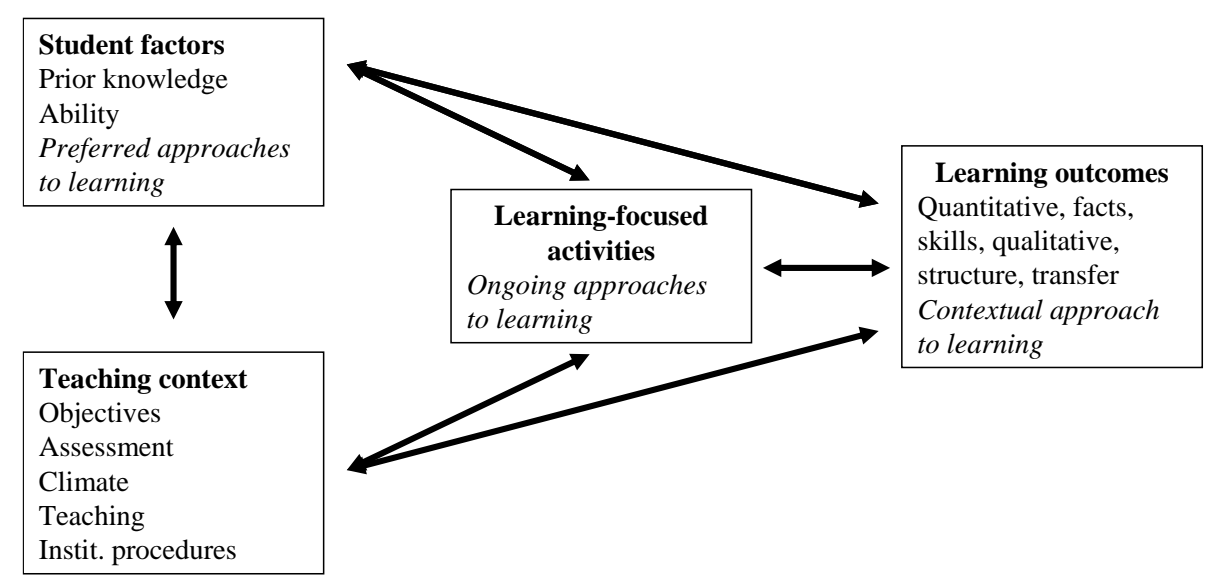

Fig. 2. The 3P model of teaching and learning (Source: Biggs et al, 2001)

The last version of ASI is the Approaches and Study Skills Inventory for Students (ASSIST, 1997; Tait et al, 1998). It measures, from a 52 items instrument, three dimensions or main scales: deep, strategic and instrumental (surface apathetic) approaches.

Strategic approach (Entwistle \& Ramsden, 1983) is associated with students primarily concerned with obtaining the highest grades, using deep and / or surface when appropriate and having a competitive and vocational motivation. Therefore, students following strategic approach are able to work effectively and regularly, to organise time and effort to obtain the maximum effects and to check progress to ensure the achievement of aims (Byrne et al, 2002a) 
- Study Processes Questionnaire, SPQ.

As Cassidy (2004) notes, SPQ is a further development of Entwistle's model, by Biggs (1985). SPQ in the original versions (1985, 1987), consists of 42 items, resulting in 6 subscales: the three approaches (surface, deep, achieving) where each approach is comprised of a motive and strategy component (Gow et al, 1994). Later versions of $S P Q$ are the revised two factors SPQ (Biggs et al, 2001), where two approaches (deep and surface) are presented by motive and strategy components and the shortened 18 items version of SPQ (Fox et al, 2001) that keeps the original three approaches by two components.

Table 2: SPQ contructs; Summary description

\begin{tabular}{|c|c|c|}
\hline Approach & Motivation & Process (strategy) \\
\hline \multirow{4}{*}{ Surface } & \multirow[b]{2}{*}{ Fear of failure } & Narrow target \\
\hline & & Rote learning of facts and ideas \\
\hline & $\begin{array}{l}\text { Desire to complete their course of } \\
\text { study }\end{array}$ & $\begin{array}{l}\text { Focusing on task components in } \\
\text { isolation }\end{array}$ \\
\hline & & Little real interest in content \\
\hline \multirow{4}{*}{ Deep } & \multirow{2}{*}{ Intrinsic interest in the subject } & Maximise meaning \\
\hline & & Relate ideas to evidence \\
\hline & \multirow{2}{*}{$\begin{array}{l}\text { Vocational relevance } \\
\text { Personal understanding }\end{array}$} & Integration of material across courses \\
\hline & & Identifying general principles \\
\hline \multirow{4}{*}{ Achieving } & \multirow{4}{*}{$\begin{array}{l}\text { Achieving high grades } \\
\text { Competing with others } \\
\text { successful }\end{array}$} & Effective use of space \& time \\
\hline & & Use any technique that achieves \\
\hline & & highest grades \\
\hline & & $\begin{array}{l}\text { Level of understanding patchy and } \\
\text { variable }\end{array}$ \\
\hline
\end{tabular}

Adapted from Fox et al (2001) and Biggs et al (2001).

Confirmatory factor and reliability analysis of 18 items version if SPQ reported by Fox et al (2001) indicates adequate properties of the instrument. One of the main rationales for a short version of an instrument is to make it easier to administer along with other scale in a larger questionnaire; however, the long version of SPQ is preferred for individual assessment.

\section{SAMPLE AND RESULTS}

Actual sample consist of 68 students at enrolled in Advanced Financial Accounting / Financial Statement Analysis, compulsory subjects, taught during 1st and 2nd terms of the 4th course in the University of Seville. The instruments consisted of a self administered questionnaire containing the SPQ 18 and the PSSQ. In order to pair data from questionnaires with grades, obtained from university databases, as well as data from 
subsequent surveys, students were asked to indicate the number of their ID card in the questionnaire.

Regarding the distribution of students by learning style, as table 3 indicates, the highest proportion of students could be labelled as diverger (50\%) with a $23.5 \%$ of students presenting an assimilator style. Converger type is only presented by $10 \%$ of the respondents.

Table 3: Learning style (PSSQ)

\begin{tabular}{ll}
\hline & Percentage \\
\hline Diverger & 50,0 \\
Converger & 10,3 \\
Accommodator & 16,2 \\
Assimilator & 23,5 \\
Total & 100,0 \\
\hline
\end{tabular}

This distribution of styles is in contrast with results provided by Duff (2004a), who found accounting students to be predominantly converger, whilst business students presenting diverger style; and Brown \& Burke (1987), that found convergent style to be the most usual for accounting students; with an increasing preference for it the exposure to accounting education and related work experience was higher. This conclusion was supported by Collins \& Milliron (1987), which reported $50 \%$ of accounting staff and $61 \%$ of accounting managers to show converger learning style. The contrast of our results with previous research is even higher given that our results indicate no significant variation on styles due to exposure to relevant work experience / placements.

Descriptive statistics for the results of SPQ are provided in table 4.

Table 4: Descriptives, SPQ contructs

\begin{tabular}{lllllll}
\hline & Minimum & Maximum & Mean & Std. Dev. & Asymmetry & Kurtosis \\
\hline SPQ Achiev. Motive & 3 & 15 & 8,96 & 2,59 & $-0,18$ & 0,22 \\
SPQ Achiev. Strat. & 4 & 15 & 10,46 & 2,42 & $-0,20$ & $-0,20$ \\
SPQ Achieving & 10 & 29 & 19,41 & 4,03 & 0,02 & 0,05 \\
SPQ Deep Motive & 5 & 15 & 10,75 & 2,23 & $-0,61$ & $-0,11$ \\
SPQ Deep Strat. & 7 & 15 & 10,51 & 1,93 & 0,22 & $-0,60$ \\
SPQ Deep & 13 & 29 & 21,21 & 3,48 & $-0,19$ & $-0,17$ \\
SPQ Surface Motive & 7 & 15 & 11,49 & 2,33 & $-0,34$ & $-0,76$ \\
SPQ Surface Strat & 4 & 15 & 8,60 & 2,14 & 0,75 & 0,90 \\
SPQ Surface & 11 & 28 & 20,01 & 3,44 & $-0,11$ & $-0,34$ \\
\hline
\end{tabular}

As the research was developed before the $2^{\text {nd }}$ term was ended, only one grade was available: Financial Accounting III. In order to test relationships between approaches to learning and learning styles with grades, a cluster analysis (as done by Byrne et al., 2004) was performed, obtaining two groups of students. The number of students in each group as well as the average grade of each cluster is shown in table 5. 
Table 5: Descriptive for clusters

\begin{tabular}{lll}
\hline \multicolumn{3}{c}{ Cluster } \\
\hline & 1 Low grades & 2 High grades \\
$\mathrm{n}$ & 38 & 35 \\
Av. grade & 4,11 & 7,22 \\
\hline
\end{tabular}

If the predominant learning styles, at higher courses, are, in certain way, associated with academic success; it could be expected to find different distributions of learning styles between the clusters. As table 6 indicates, there are no significant differences (Chi square test) between students with high grades and students with low grades.

Table 6: Contingency table learning style by grades

\begin{tabular}{lccc}
\hline PSSQ & low grades & high grades & total \\
\hline Diverger & $48 \%$ & $48 \%$ & $48 \%$ \\
Converger & $9 \%$ & $8 \%$ & $8 \%$ \\
Accommodator & $17 \%$ & $16 \%$ & $17 \%$ \\
Assimilator & $26 \%$ & $28 \%$ & $27 \%$ \\
& $100 \%$ & $100 \%$ & $100 \%$ \\
\hline
\end{tabular}

The differences with results in table 3 are due to some differences in the sample (some students did not indicate their ID, therefore are not assigned to any cluster)

In the same line, comparisons of approaches to learning by grade cluster are presented in table 7. Successful students present no differences in achieving and deep approaches to low grades students. Only surface approach appears to be related with grades.

Table 7: Approaches to learning by grade

\begin{tabular}{llllll}
\hline & & $N$ & Mean & Std. Dev. & T-test sig. \\
\hline SPQ_AM & low grades & 23 & 8,83 & 2,59 & n.s. \\
& high grades & 25 & 9,36 & 2,55 & \\
SPQ_AS & low grades & 23 & 10,61 & 2,06 & n.s. \\
& high grades & 25 & 10,68 & 2,72 & \\
SPQ_A & low grades & 23 & 19,43 & 3,40 & n.s. \\
& high grades & 25 & 20,04 & 4,69 & \\
SPQ_DM & low grades & 23 & 10,96 & 2,06 & n.s. \\
& high grades & 25 & 10,48 & 2,37 & \\
SPQ_DS & low grades & 22 & 10,68 & 1,62 & n.s. \\
& high grades & 25 & 10,32 & 2,30 & \\
SPQ_D & low grades & 22 & 21,50 & 3,23 & n.s. \\
& high grades & 25 & 20,80 & 3,89 & \\
SPQ_SM & low grades & 23 & 12,17 & 2,15 & 0,08 \\
& high grades & 24 & 11,08 & 2,12 & \\
SPQ_SS & low grades & 23 & 9,35 & 2,06 & n.s. \\
& high grades & 25 & 8,56 & 2,29 & \multirow{2}{*}{0,026} \\
SPQ_S & low grades & 23 & 21,52 & 3,15 & \\
& high grades & 24 & 19,42 & 3,12 & \\
\hline
\end{tabular}


Students in the low grades cluster score higher in surface approach than their colleagues. Those results are partially consistent with results reported in the literature, given that no relationship appeared between deep approach and academic success.

The results of a correlation analysis (table 8) confirm the results above. Only surface approach scores show significant coefficients. The sign of the correlation is, as expected, negative and quite strong (42\%). It is to be noted that the score in the concrete experience (CE) - abstract conceptualization (AC) dimension appears to be related with the grades. Higher scores on the CE-AC dimension, that means more acute abstract conceptualization preference, are strongly related with higher grades.

\section{DISCUSSION}

This paper aimed to explore the learning style profiles and approaches to learning showed by a sample of Spanish accounting students as well as the relationship of those profiles with academic performance.

The instruments used were the short version of the Study Process Questionnaire (SPQ; Fox et al, 2001), to explore the approaches to learning and the Problem Solving Style Questionnaire (PSSQ, Romero et al, 1992) for learning styles.

PSSQ was selected instead other more popular ELM based instruments due to the reported weaknesses of most used inventories. Shorter versions of SPQ was preferred to longer versions (such US ASSIST) in order to avoid excessive length for the questionnaire, which included both instruments.

Regarding the distribution of students by learning style, the highest proportion of students could present the diverger style $(50 \%)$, followed by $23.5 \%$ of students presenting an assimilator style. Converger type is presented only by $10 \%$ of students. Those results are in contrast with reported results, which indicate converger as the most usual style for accounting students. Association between grades and styles was found, although students scoring high in the concrete experience (CE) - abstract conceptualization (AC) dimension tend to obtain higher grades.

Regarding approaches to learning; students obtaining lower grades scores significantly higher in surface approach. This result is confirmed in the correlation analysis, which shows a strong negative correlation between scores in surface approach and grades and is consistent with theoretical framework and reported results. However, no relationship appeared between any of the other two approaches and academic success. 


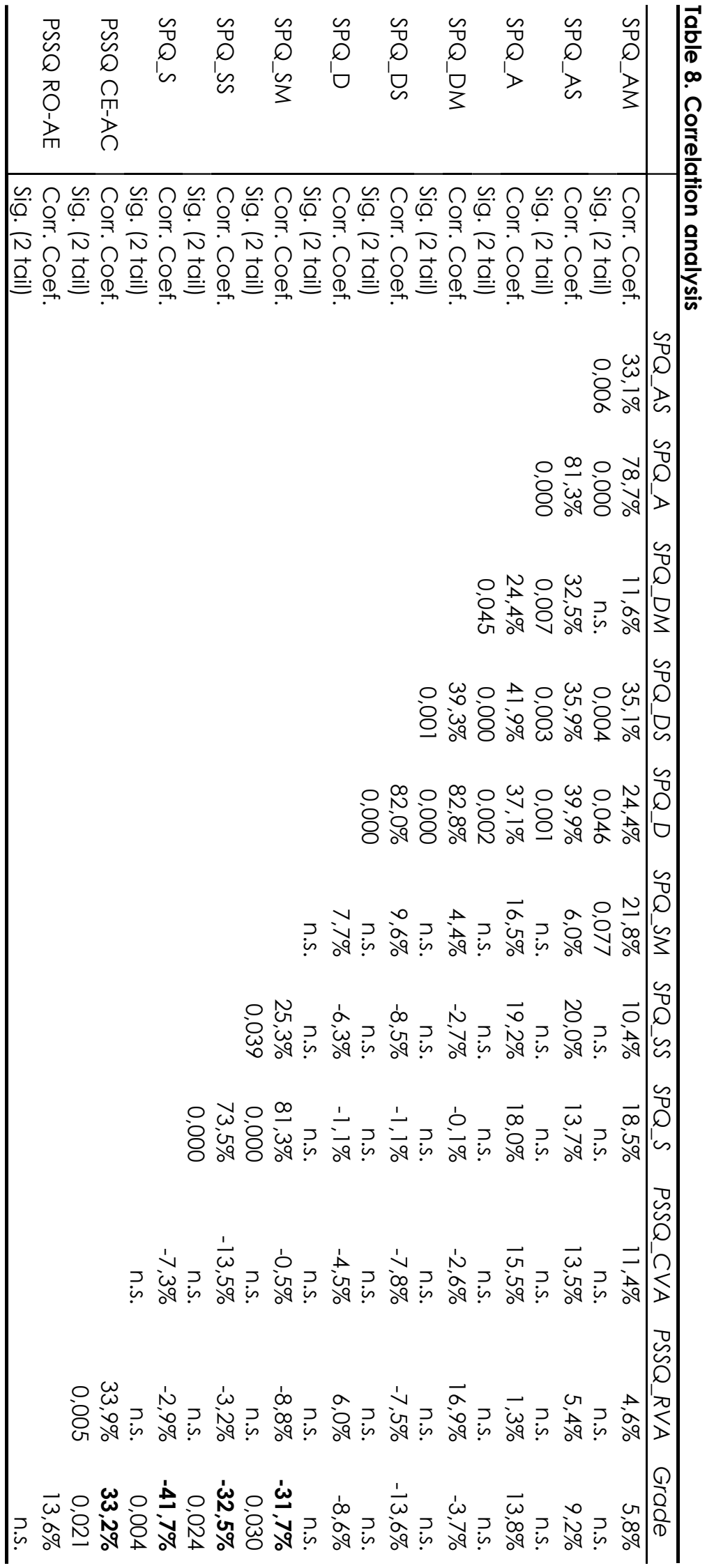




\section{Limitations and extensions}

The main limitations of the paper derive from its nature of emerging research. Sample must be broadened, including both, more students at the higher courses as well as students at entry level, in order to investigate (I) potential evolution of learning styles distribution (II) differences in approaches to learning.

Reliability and factorial analyses, that need larger samples in order to show consistent results, should be included.

\section{REFERENCES}

ASSIST (1997) Approaches and Study Skills Inventory for Students. Edinburgh, Centre for Research on Learning and Instruction, University of Edinburgh.

Ausubel, DP. (1968). Educational psychology: a cognitive view. Holt, Rinehart and Winston.

Baker, RE, Simon, JR \& Bazeli, FP. (1986). An assessment of the learning style preferences of accounting majors. Issues in Accounting Education. 1, 1, 1-12.

Biggs J.; Kember D. \& Leung D.Y.P. (2001). The revised two-factor Study Process Questionnaire: R-SPQ-2F. British Journal of Educational Psychology, 71, 1, 133149

Biggs, J.B. (1978). Individual and group differences in study process, British Journal of Educational Psychology, 48, 3, 266-79.

Biggs, J.B. (1985). The role of metalearning in study processes. British Journal of Educational Psychology, 55, 185-212.

Biggs, J.B. (1987). Student Approaches to Learning and Studying. Hawthorn: Australian Council for Educational Research.

Booth, P; Luckett, P. \& Mladenovic, R. (1999). The quality of learning in accounting education: the impact of approaches to learning on academic performance. Accounting Education, 8, 4, 277-300.

Bostrom, R.P.; Olfman, L. \& Sein, M.K. (1990). The Importance of Learning Style in EndUser Training. MIS Quarterly, 14, 1, 101-119.

Brown, H.D. \& Burke, R.C (1987). Accounting education: a learning styles study of professional-technical and future adaptation issues. Journal of Accounting Education, 5, 187-206.

Byrne, M.; Flood, B. \& Willis, P. (2002b). The relationship between learning approaches and learning outcomes: a study of Irish accounting students. Accounting Education. An International Journal. 11, 1, 27-42.

Byrne, M; Flood, B \& Willis, P (2002). Approaches to learning of European business students. Journal of Further and Higher Education, 21-1, 19-28.

Byrne, M; Flood, B \& Willis, P (2004). Using the student learning framework to explore the 
variation in academic performance of European business students. Journal of Further and Higher Education, 28-1, 67-78.

Byrne, M; Flood, B \& Willis, P (2004b). Validation of the Approaches and Study Skills Inventory for Students (ASSIST) using accounting students in the USA and Ireland: a research note. Accounting Education, 13-4, 449-459.

Cassidy, S. (2004). Learning Styles: An overview of theories, models and measures. Educational Psychology. 24,4, 419-444.

Collins, J.H. and Milliron, V.C. (1987) A measure of professional accountants' learning style. Issues in Accounting Education. 2, 2, 193-206.

Curry, L. (1987). Integrating Concepts of Cognitive Or Learning Style: A Review with Attention to Psychometric Standards. Ottawa, ON. Canadian College of Health Service Executives.

Duff, A. \& Duffy, T. (2002). Psychometric properties of Honey \& Mumford's Learning Styles Questionnaire (LSQ). Personality and Individual Differences, 33, 1, 147-163.

Duff, A. (1999). Access policy and approaches to learning. Accounting Education. An International Journal. 8, 2, 99-110.

Duff, A. (2004a). A Note on the Problem Solving Style Questionnaire: An alternative to Kolb's Learning Style Inventory? Educational Psychology. 24, 5, 699-709.

Duff, A. (2004b). Understanding academic performance and progression of first-year accounting and business economics undergraduates: the role of approaches to learning and prior academic achievement. Accounting Education. An International Journal. 13, 4, 409-430.

Duff, A. (2004c). The revised approaches to studying inventory and its use in management education. Active learning in higher education. 5, 1, 56-72.

English, L; Luckett, P. \& Mladenovic, R. (2004). Encouraging a deep approach to learning through curriculum design. Accounting Education. 13, 4, 461-488.

Entwistle, N.J \& Entwistle, A. (1991). Contrasting forms of understanding for degree examinations: the students experience and its implications. Higher Education, 205, 227.

Entwistle, N.J. \& Ramsden, P. (1983). Understanding student learning. London. Croom Helm.

Entwistle, N.J. \& Tait, H. (1995). The Revised Approaches to Studying Inventory. Edinburgh: Centre for Research on Learning and Instruction, University of Edinburgh.

Entwistle, N.J. and Wilson, J.D. (1970) Personality, study methods and academic performance, University Quarterly, 21, 147-46.

Entwistle, N.J., Thompson, J.B. and Wilson. J.D. (1974) Motivation and study habits, Higher Education, 3, 4, 379-96.

Entwistle, N; Hanley, M \& Hounsell, D (1979). Identifying distinctive approaches to 
studying. Higher Education, 8, 365-380.

Fernandez-Polvillo, C. F., \& Montaño, J. L. A. (2015). Enfoques de aprendizaje: un análisis de las propiedades psicométricas básicas de tres cuestionarios cortos. Educade: revista de educación en contabilidad, finanzas y administración de empresas, (6), 23-34.

Fox R. A.; McManus I.C. \& Winder B. C. (2001). The shortened Study Process Questionnaire: An investigation of its structure and longitudinal stability using confirmatory factor analysis. British Journal of Educational Psychology. 71, 4, 511-530.

Gow, L; Kember, D \& Cooper, B. (1994). The teaching context and approaches to study of accountancy students. Issues in Accounting Education, 9, 1, 118-130.

Hall, M.; Ramsay, A. \& Raven, J. (2004). Changing the learning environment to promote deep learning approaches in first-year accounting students. Accounting Education. 13, 4, 489-505.

Hassall, T \& Joyce, J (2001). Approaches to learning of management accounting students. Education + Training. 43, 3, 145-152.

Honey, P \& Mumford, A (1992). The manual of learning styles. Berkshire. Peter Honey.

Jackling, B. (2005). Perceptions of the Learning Context and Learning Approaches: Implications for Quality Learning Outcomes in Accounting. Accounting Education: An International Journal. 14, 3, 271-291.

Kolb, D. A. (1976). Learning Style Inventory: technical manual. Boston, MA: McBer and Company.

Kolb, D. A. (1985). Learning Style Inventory: self-scoring inventory and interpretation booklet. Boston, MA: McBer and Co.

Kolb, D.A. (1984). Experiential learning. Englewood Cliffs, NJ. Prentice Hall Inc.

Lange, P. \& Mavondo, F. (2004). Gender and motivational differences in approaches to learning by a cohort of open learning students. Accounting Education. 13, 4, 431-448.

Lucas, U. (2001). Deep and surface approaches to learning within introductory accounting: a phenomenographic study Accounting Education: An International Journal. 10, 2, 161-184.

Marton, F. \& Säljö, R. (1976). On qualitative differences in learning. Outcome and process. British Journal of Educational Psychology, 46, 4-11.

McKee, T.E., Mock, T.J. \& Fleming Ruud, T. (1992) Comparison of Norwegian and United States accounting students' learning style preferences. Accounting Education: an international journal. 1, 4, 321-41.

Pask, G. (1976). Styles and strategies of learning, British Journal of Educational Psychology, 46, 2, 128-48.

Ramburuth, P. \& Mladenovic, R. (2004). Exploring the relationship between students' orientations to learning, the structure of students' learning outcomes and 
subsequent academic performance. Accounting Education. 13, 4, 507-527.

Rayner, S \& Riding, RJ (1997). Towards a Categorisation of Cognitive Styles and Learning Styles. Educational Psychology, 17, 5-27.

Romero, J. E., Tepper, B. J., \& Tetrault, L. A. (1992). Development and validation of new scales to measure Kolb's (1985) learning style dimensions. Educational and Psychological Measurement, 52, 171-180.

Stout, D. E., \& Ruble, T. L. (1991a). The LSI and accounting education research: a cautionary view and suggestions for future research. Issues in Accounting Education, 6, 41-52.

Stout, D. E., \& Ruble, T. L. (1991b). A reexamination of accounting students' learning styles. Journal of Accounting Education, 9, 341-354.

Stout, D.E. and Ruble, T.L. (1994) A reassessment of the Learning Style Inventory (LSI1985 ) in accounting education research. Journal of Accounting Education. 12, 2, 89-104.

Swailes, S. \& Senior. B. (1999). The Dimensionality of Honey and Mumford's Learning Styles Questionnaire. International Journal of Selection and Assessment. 7, 1, 111.

Tait, H. \& Entwistle, N.J. (1995). Revised Approaches to Studying Inventory 1995. Edinburgh: Centre for Learning and Instruction, University of Edinburgh.

Tait, H., Entwistle, N.J. \& McCune, V. (1998) ASSIST: a reconceptualisation of the approaches to studying inventory, in: Rust, C. (Ed.) Improving Student Learning: Improving Students as Learners. Oxford: The Oxford Centre for Staff and Learning Development.

Tepper, B. J., Tetrault, L. A., Braun, C. K., \& Romero, J. E. (1993). Discriminant and convergent validity of the Problem Solving Style Questionnaire. Educational and Psychological Measurement, 53, 437-444.

Willcoxson, L., \& Prosser, M. (1996). Kolb's Learning Style Inventory (1985): review and further study of validity and reliability. British Journal of Educational Psychology, 66, 247-257.

Zhang, L.F. \& Watkins, D. (2001). Cognitive development and student approaches to learning: An investigation of Perry's theory with Chinese and U.S. University students. Higher Education. 41, 3, 239-261. 